\title{
Seasonal migration and environmental conditions of Pacific halibut Hippoglossus stenolepis, elucidated from pop-up archival transmitting (PAT) tags
}

\author{
Timothy Loher ${ }^{1, *}$, Andy Seitz ${ }^{2}$ \\ ${ }^{1}$ International Pacific Halibut Commission, PO Box 95009 Seattle, Washington 98145, USA \\ ${ }^{2}$ US Geological Survey, Alaska Science Center, 1011 East Tudor Road, MS 701, Anchorage, Alaska 99503, USA
}

\begin{abstract}
Pop-up archival transmitting (PAT) tags were used to study the fall migration of halibut in the Gulf of Alaska (GOA). We tagged 6 Pacific halibut Hippoglossus stenolepis on summer feeding grounds in the eastern GOA and another 6 in the western GOA from June 13 to August 6, 2002. The tags were programed to be released from the fish on January 15, 2003, at the height of the winter spawning season: 10 tags successfully detached, transmitted archived environmental data (depth and temperature), and generated accurate latitude-longitude coordinates shortly after pop-up; 2 tags deployed off SE Alaska were lost. The tags revealed that 6 fish had moved a considerable distance $(>200 \mathrm{~km}$ ) between tagging and pop-up, and all of these had moved northward to some extent. The longest of the observed migrations was from the southern Alaska Peninsula to Yakutat Bay, a linear displacement of $1153 \mathrm{~km}$; 4 fish showed little evidence of geographic displacement, exhibiting migrations that ranged only from 30 to $69 \mathrm{~km}$. Although 2 fish had moved inshore by the end of the tagging period, all other fish had moved offshore regardless of their overall migration distance. The precise timing of offshore movements varied, beginning as early as August and as late as January. These observations generally corroborate conventional tagging, indicating migration of halibut toward winter spawning grounds in the northern GOA, and movement of fish to deep water in fall. However, no single stereotypic migration behavior was apparent, and a variety of vertical movement patterns and temperature profiles were observed. Halibut spent most time in waters of 5 to $7^{\circ} \mathrm{C}$, but experienced temperatures ranging from 2.6 to $11.6^{\circ} \mathrm{C}$. Depth observations ranged from 0 to $736 \mathrm{~m}$, with summertime activity concentrated in depths from 0 to $400 \mathrm{~m}$, and halibut that exhibited offshore movement were typically observed at 300 to $700 \mathrm{~m}$ by mid-winter. Vertical movement (short-period changes in depth) varied among fish and over time, with some fish displaying little vertical activity, others displaying short periods of activity, and still others displaying considerable activity throughout their time at liberty.
\end{abstract}

KEY WORDS: Pacific halibut - Hippoglossus stenolepis - Gulf of Alaska - Seasonal migration · Behavior · Archival tags

Resale or republication not permitted without written consent of the publisher

\section{INTRODUCTION}

A refined understanding of the movements of eastern Pacific halibut is desirable because recent market concerns have generated pressure to extend the fishery into the mid-winter spawning season, and the potential ramifications are unknown. Ecologically, it is important to examine metapopulation structure and life-history strategies in order to avoid overexploitation of spawning groups that display unique production characteristics or exist in seasonal isolation. From a pragmatic perspective, a clearer understanding of seasonal migration is needed to ensure that redistribution of biomass does not effectively transfer quota among 'regulatory areas' (Leaman et al. 2002). The commercial fishery in Alaska and Canada is managed under 
'individual quota' (IQ) systems with a season that extends from late February through mid-November. Annual harvest guidelines are established independently within the series of regulatory areas that encompass the geographic range of the stock. The International Pacific Halibut Commission (IPHC) uses an annual assessment process to establish areaspecific quotas, wherein commercial catch per unit effort (CPUE), age and size structure, and data from annual, setline, stock-assessment surveys provide the primary inputs to the assessment model. As such, areaspecific quotas largely reflect summer distribution because there is no targeted winter fishery, and IPHC setline surveys are conducted in summer.

Whereas commercial fisheries are concentrated along the shelf on shallow-water feeding grounds, spawning has been documented during winter in deep water along the shelf break, from the Queen Charlotte Islands, British Columbia, to the Pribilof Canyon in the southeast Bering Sea (St. Pierre 1984). Rather than simply moving offshore to spawn, halibut may move considerable distances alongshore during their seasonal migration. Halibut appear to congregate in the north-central Gulf of Alaska (GOA) during winter, and of particular management concern is that fish tagged off SE Alaska during the winter have been recaptured in the Canadian fishery (Leaman et al. 2002). This suggests that a seasonal mixing might occur between countries and among regulatory areas. Winter fisheries in Alaska could intercept halibut that would spend the summer in Canadian waters.

In addition to gaps in our understanding of their seasonal migration, very little is known regarding the vertical distribution of halibut during winter or the in situ environmental conditions to which they are subjected. Halibut have been reported from as deep as $1100 \mathrm{~m}$ (Mecklenburg et al. 2002), and the IPHC presently uses a depth of $\sim 550 \mathrm{~m}$ to define the summertime limit of the halibut habitat (Clark \& Hare 2002). However, detailed reports of depth-specific distribution are lacking, especially during winter. St. Pierre (1984) has provided the most complete documentation of winter distribution, but very little regarding the depth strata in which individuals are expected to reside, and no information regarding the temperatures experienced. There is evidence that the abundance and distribution of juvenile halibut is governed by temperature (Novikov 1968, Best 1977), and the same may be true for adults. Preferred temperatures might influence movement and distribution of adult halibut, but there is a paucity of information regarding the distribution of individuals in relation to hydrographic parameters.

In this study, pop-up archival transmitting (PAT) tags were used to study seasonal migration and environmental conditions experienced by large halibut. Conventional tagging has failed to give us a clear and unbiased picture of seasonal migrations for the Pacific halibut population. The interpretation of conventional tag data is confounded by variability in fishing effort, the efficiency associated with different gear types, and geographic variability in tag reporting rates, all of which can alter patterns of tag recovery and migration estimates derived from them (Hilborn et. al 1995, Heifetz \& Maloney 2001). This is especially true for the study of winter migration in Pacific halibut because the targeted fishery is closed from mid-November through early March and retention of halibut is prohibited for all other gear types. The cumulative January and February recovery rate for conventional tags released by the IPHC is $<0.1 \%$ (IPHC unpubl. data), which seriously limits the utility and effectiveness of conventional tagging for winter-spawning research. PAT tags represent a novel technology that has proven effective for use on halibut in Alaska (Seitz et al. 2003) and allows us to study movements and behavior without the need to recapture fish. PAT tags collect temperature, depth and light data at regular intervals, detach from the fish on a pre-programed date, and broadcast the stored data and accurate endpoint latitude-longitude position to Argos satellites. The primary objective of this study was to tag fish on the summer grounds of the GOA and observe movement to winter grounds without the need to recapture fish during the fishery closure. In particular, our ultimate goal was to examine migration patterns, especially the extent to which alternative migration strategies might affect spawning-stock structure and seasonal biomass distribution. The research was primarily observational, providing fishery-independent migration data and in situ behavioral observations in the form of depth profiles and temperatures encountered by wild halibut.

\section{MATERIALS AND METHODS}

Tagging. We tagged 12 adult halibut with PAT tags (Wildlife Computers) between June 13 and August 6, 2002, during the IPHC stock-assessment survey. PAT tags were attached to the halibut with a titanium dart attached to the PAT with $130 \mathrm{~kg}$ test, monofilament fishing-line covered with adhesive-lined shrink-wrap tubing. The dart was inserted in the eyed side of the fish, lodged beneath the dorsal pterygiophores (i.e. the bones extending from the tips of the ribs to the fin rays). The insertion was approximately $4 \mathrm{~cm}$ below the lower edge of the dorsal fin, just posterior to the widest point of the body. Halibut were tagged in the GOA along two transect lines with deployment sites spaced roughly $200 \mathrm{~km}$ apart (see Fig. 1 \& Table 1). The first transect (eastern GOA) extended from Vancouver Island, British Columbia, to just SW of Cape Spencer, 
Alaska. The second transect (western GOA) extended from just east of Sanak Island to south Cape Cleare, Alaska.

Endpoint locations. Tags were programed to detach (pop-up) at 01:00 h coordinated universal time (UTC) on January 15, 2003. Mid-January was chosen because this represents the height of the spawning season (St. Pierre 1984). Tag locations after pop-up were estimated by Service Argos (satellite data processing company) using the Doppler shift of each tag signal as received by polar orbiting satellites on successive passes (Hays et al. 2001). Argos provides an estimate of location accuracy in the form of a 'location class' (LC). Each position estimate is assigned an $\mathrm{LC}$ ranging from 0 to 3 , or listed as the letters $A, B$, or Z, where latitudinal and longitudinal accuracy are LC3 $=<150 \mathrm{~m}, \mathrm{LC} 2=$ 150 to $350 \mathrm{~m}, \mathrm{LC} 1=350$ to $1000 \mathrm{~m}, \mathrm{LC} 0=>1000 \mathrm{~m}$; A and $\mathrm{B}$ have no precision estimate, and $\mathrm{Z}$ is rejected as implausible. The pop-up locations reported here represent the first location for which an LC of 1 to 3 has been provided.

Light-based longitude estimates. In addition to endpoint location derived from Argos satellites, daily longitude estimates during time at liberty were determined using the archived light data. Light levels can theoretically be used to determine tag location, whereby time of local solar noon is used as an indicator of longitude and total day-length as an indicator of latitude (Welch \& Eveson 1999). Light-based longitude estimates were produced by Wildlife Computers' proprietary software, Global Position Estimator (GPE), using the ambientlight data (Seitz et al. in press a). GPE is a suite of programs that post-process light-level readings archived in PAT tags and then produce daily geolocation estimates. Days were rejected if light-level curves did not exhibit smoothly sloping light levels from high to low or low to high. GPE was used to calculate longitude for the remaining data based on the local noon of the tag (mean of the sunrise and sunset times) compared to $12: 00 \mathrm{~h}$ UTC. Estimated longitude values that were outside the published range of the Pacific halibut (west of Hokkaido, Japan [Longitude $140^{\circ} \mathrm{E}$ ] or east of northern Baja, Mexico [ $\left[17^{\circ} \mathrm{W}\right]$; Mecklenburg et al. 2002) were considered outliers and were rejected. Latitude is not reported because it can be highly biased for tags located at depth (Seitz et al. in press a).

Note that individual light-based longitude estimates in the GOA include mean errors of $\sim 2^{\circ}$ at depths of $150 \mathrm{~m}$ (Seitz et al. in press a), and mean error is expected to increase with increasing depth. Error magnitude for any single longitude estimate is dependent upon factors influencing ambient light, such as cloud cover and turbidity. Thus, individual, light-based, longitude estimates should be viewed cautiously. However, errors within a series of estimates are expected to be evenly distributed around the true position, such that a sufficiently large series of estimates will accurately detect that position. Fixed instruments demonstrate that daily longitude estimates are just as likely to be in error to the east as to the west (Seitz et al. in press a). As a result, trends in position estimates are more reliable than the individual points comprising them. For example, a single point displaced westward of a group of easterly estimates probably indicates an outlier influenced by error, whereas if longitude estimates move regularly from east to west over time then it is likely that the fish moved east to west and such a trend can be informative.

Behavioral data. Tags were programed to record temperature $\left(0.05^{\circ} \mathrm{C}\right.$ resolution $)$, and depth $(0.5 \mathrm{~m}$ resolution) at $1 \mathrm{~min}$ intervals, and light level at $4 \mathrm{~min}$ intervals. Temperature and depth data were then summarized into $12 \mathrm{~h}$ periods by onboard software to reduce the amount of data sent through the Argos satellites. The transmitted data were received as 'processed files' that contained the percent of time spent at specified depth and temperature intervals (i.e. bins). Temperature data were received with $0.2^{\circ} \mathrm{C}$ resolution in the following bins: $<1^{\circ} \mathrm{C}, 1.1-3.0^{\circ} \mathrm{C}, 3.1-5.0^{\circ} \mathrm{C}$, $5.1-7.0^{\circ} \mathrm{C}, 7.1-9.0^{\circ} \mathrm{C}, 9.1-11.0^{\circ} \mathrm{C}, 11.1-13.0^{\circ} \mathrm{C}, 13.1-$ $15.0^{\circ} \mathrm{C}, \quad 15.1-17.0^{\circ} \mathrm{C}, \quad 17.1-20.0^{\circ} \mathrm{C}, 20.1-30.0^{\circ} \mathrm{C}$ and $30.1-60.0^{\circ} \mathrm{C}$. Depth data were received with $4 \mathrm{~m}$ resolution in the following bins: surface, $0-10.0 \mathrm{~m}, 10.5-$ $50.0 \mathrm{~m}, 50.5-100.0 \mathrm{~m}, 100.5-150.0 \mathrm{~m}, 150.5-200.0 \mathrm{~m}$, 200.5-250.0 m, 250.5-300.0 m, 300.5-400.0 m, 400.5$500.0 \mathrm{~m}, 500.5-750.0 \mathrm{~m}$ and $750.5-1000.0 \mathrm{~m}$. Daily mean depth was determined for each fish, calculated as a time-weighted average using the median depth of each bin visited during each day. The resulting value aids interpretation of long-term depth profiles, since it condenses large amounts of daily information into a single value. Additionally, to provide insight into water column structure, ambient water temperatures were reported for a suite of 8 depths (referred to by Wildlife Computers as 'PDT data') during each summary period. These provided the minimum depth experienced, maximum depth experienced, and 6 additional depths spaced equidistantly between the maximum and minimum, as well as the corresponding temperature at each of the 8 depths. For the purposes of this paper, maximum and minimum observed temperatures represent the absolute maximum and minimum reported among all reported depths. This temperature information should provide a reasonable indicator of the range of temperatures experienced by the fish during each summary period, but it should be noted that the actual range of temperatures experienced by a fish could have been greater than reported if true temperature extremes occurred at depths other than the 8 included in the PDT file. 


\section{RESULTS}

\section{Tagging}

Fish were tagged between June 13 and August 6, 2002, and ranged in length from 106 to $150 \mathrm{~cm}$ in forklength (Table 1). Based on the size-specific sex ratio observed in the Gulf of Alaska during the 2002 IPHC stock-assessment survey, the smallest fish tagged possessed approximately $80 \%$ likelihood of being female and the largest nearly $100 \%$ (IPHC unpubl. data).

\section{Location data}

Pop-up locations

Of the 12 tags deployed, 10 successfully detached from their host fish and reported to the Argos system (Table 1). Transmissions from 9 of the successful tags were received on the expected pop-up date (January 15, 2003); 1 tag (S-133) did not begin reporting until January 17, with its pop-up location determined at 09:06 h UTC. Pop-up locations (Table 1, Fig. 1) revealed 2 displacement patterns for adult halibut: 4 tags popped-up within $70 \mathrm{~km}$ of initial release, providing little evidence of substantial overall displacement between summer and mid-January; the remaining 6 fish moved considerable distances between release and tag pop-up, with linear displacements ranging between 207 and $1153 \mathrm{~km}$. Halibut with displacement
$>200 \mathrm{~km}$ moved northward between tagging and popup. The tags showed that 3 fish crossed IPHC regulatory area boundaries: 2 halibut tagged in Canada (Area 2B) moved into SE Alaska (2C), and 1 fish tagged in the western GOA moved to the northern GOA (from Area 3B to 3A). Most halibut moved offshore between tagging and pop-up, but 2 moved to inshore waters: $\mathrm{S}-105$ was tagged $\sim 35 \mathrm{~km}$ west of Baranof Island and moved into Chatham Strait, while S-133 was tagged $\sim 30 \mathrm{~km}$ south of Cape Cleare and moved into Cook Inlet (Fig. 1). Note that although the signal for S-133 was not received until more than $2 \mathrm{~d}$ following programed release, analyses of post-pop-up drift rates conducted elsewhere (Loher \& Seitz in press) indicate that the actual pop-up location would have been even farther inside Cook Inlet had the tag been adrift the entire time.

\section{Light-based longitude estimates}

For all but 1 halibut, light-based longitude estimates showed no evidence that fish tagged in the eastern GOA (Area 2) moved out of Area 2 during their time at liberty, or that fish tagged in the western GOA (Area 3) moved into Area 2, whereby the boundary between those areas was defined as $\sim 140^{\circ} \mathrm{W}$ longitude (Fig. 2, right-hand graphs); 1 eastern gulf fish (S-105) produced longitude estimates west of $140^{\circ} \mathrm{W}$. Light-based longitude estimates showed evidence of potential travel between the GOA and Bering Sea (Area 4) for only 1 fish (S-137); 2 estimates generated for S-137 in

Table 1. Hippoglossus stenolepis. Size of fish tagged (fork length, FL), tag release and pop-up locations (Latitude N, Longitude W), reception time (coordinated universal time, UTC) of transmissions used for location determination, Argos location class (LC) associated with transmissions, and linear displacement of each halibut between release and pop-up. dnr indicates that a tag did not report after pop-up. Errors associated with each pop-up location estimated by Argos, based on location class (see 'Materials and methods; Endpoint locations' for details). Note: S-133 popped up on January 17, all other tags on January 15, 2003

\begin{tabular}{|c|c|c|c|c|c|c|c|c|}
\hline \multirow{2}{*}{ Tag No. } & \multirow{2}{*}{$\begin{array}{l}\text { FL } \\
(\mathrm{cm})\end{array}$} & \multicolumn{2}{|c|}{ Release location } & \multicolumn{2}{|c|}{ Pop-up location } & \multirow{2}{*}{ UTC } & \multirow{2}{*}{$\mathrm{LC}$} & \multirow{2}{*}{$\begin{array}{l}\text { Displacement } \\
(\mathrm{km})\end{array}$} \\
\hline & & ${ }^{\circ} \mathrm{N}$ & ${ }^{\circ} \mathrm{W}$ & ${ }^{\circ} \mathrm{N}$ & ${ }^{\circ} \mathrm{W}$ & & & \\
\hline \multicolumn{9}{|c|}{ Eastern Gulf } \\
\hline S-101 & 141 & 50.324 & 128.183 & 55.97 & 135.399 & $04: 50$ & 1 & 790 \\
\hline S-102 & 106 & 51.834 & 129.787 & 51.667 & 130.134 & $03: 34$ & 1 & 30 \\
\hline S-103 & 130 & 53.336 & 133.100 & 55.051 & 134.354 & $02: 47$ & 2 & 207 \\
\hline S-104 & 125 & 55.167 & 134.018 & $\operatorname{dnr}$ & dnr & - & - & - \\
\hline S-105 & 115 & 56.500 & 135.55 & 56.564 & 134.621 & $06: 30$ & 1 & 57 \\
\hline S-106 & 119 & 57.834 & 136.564 & dnr & dnr & - & - & - \\
\hline \multicolumn{9}{|c|}{ Western Gulf } \\
\hline S-133 & 111 & 59.486 & 147.876 & 59.756 & 152.431 & 09:06 & 1 & 258 \\
\hline $\mathrm{S}-135$ & 122 & 58.500 & 150.773 & 59.631 & 143.107 & 03:12 & 1 & 455 \\
\hline $\mathrm{S}-136$ & 122 & 56.833 & 152.581 & 58.823 & 148.429 & 02:09 & 2 & 330 \\
\hline S-137 & 150 & 55.703 & 156.434 & 56.165 & 156.301 & $02: 49$ & 2 & 52 \\
\hline $\mathrm{S}-138$ & 112 & 54.675 & 158.417 & 58.772 & 140.968 & $02: 48$ & 1 & 1153 \\
\hline S-139 & 117 & 54.177 & 161.561 & 54.669 & 160.909 & $12: 20$ & 1 & 69 \\
\hline
\end{tabular}




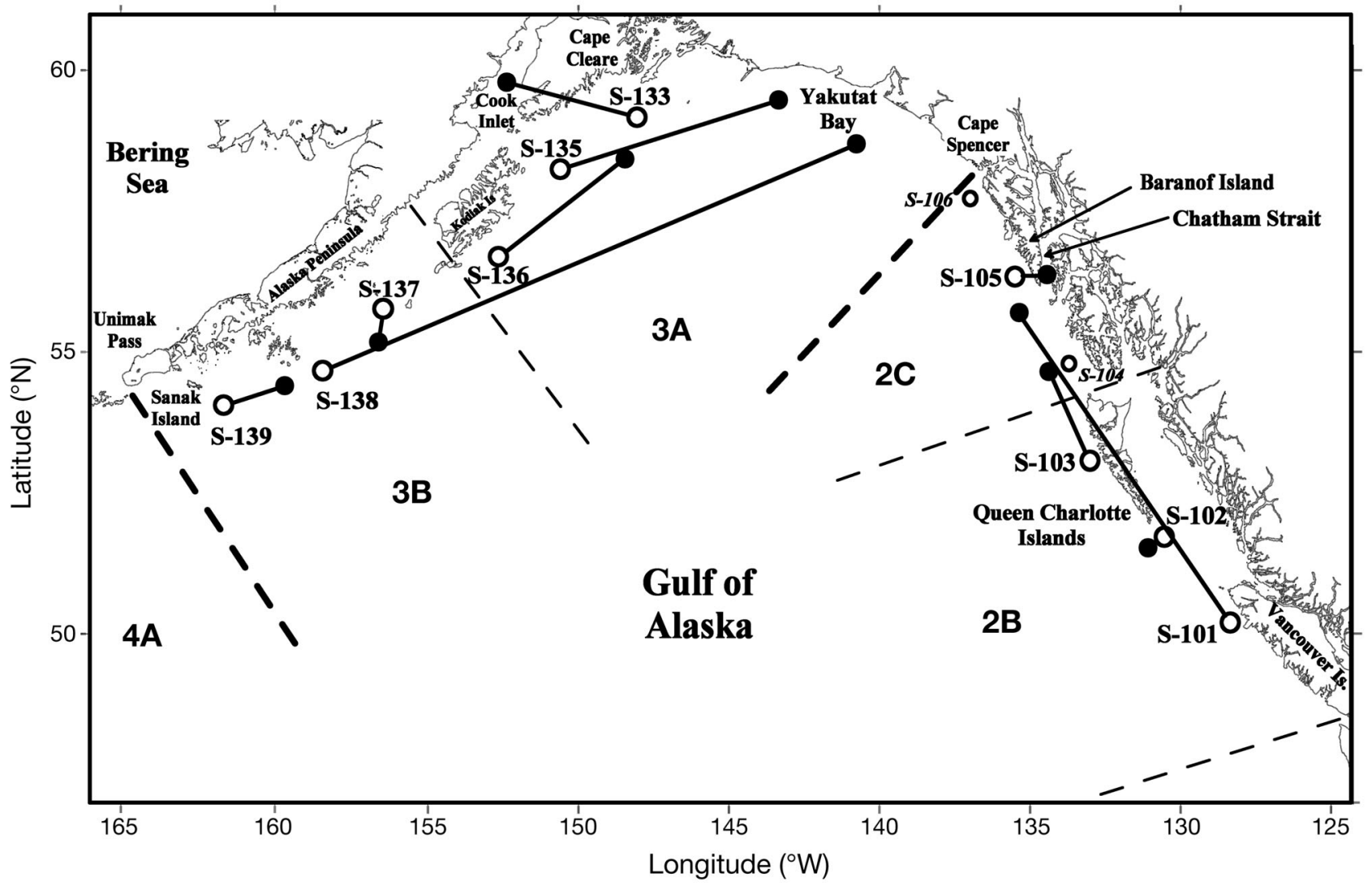

Fig. 1. Location of IPHC 'regulatory areas' in Gulf of Alaska, geographic features, and PAT tag release and pop-up locations used for Pacific halibut Hippoglossus stenolepis. Dashed lines indicate regulatory area boundaries. (O) Tag-release locations, labeled with tag numbers referred to in text; $(\mathbf{O})$ tag pop-up locations, connected by continuous lines to release locations (note: these lines are not meant to imply path taken by the fish). Tags labeled in italics (S-104 and S-106) did not successfully report at time of programed release

August and September would have placed the fish near Unimak Pass, west of $165^{\circ} \mathrm{W}$ (Fig. 2). This suggests that it may have briefly moved into the eastern Bering Sea. However, all other estimates were well to the east, suggesting residence primarily within the western GOA.

\section{Environmental data}

Depth

The shallowest overall depth profile was recorded by S-133 (Fig. 2) which spent considerable time within the 0 to $10 \mathrm{~m}$ depth bin during October and recorded minimum depths of $0 \mathrm{~m}$ on several days. Greatest depths were recorded by S-103 and S-105, both of which made forays to depths of over $600 \mathrm{~m}$ in December and January. S-103 visited the single deepest absolute depth, recording $736 \mathrm{~m}$ on December 31 (Fig. 3).

Tagged halibut demonstrated a broad range of vertical movement patterns over time, ranging from extended periods at relatively constant depth to periods of frequent or abrupt change in depth, both seasonally and over short periods. Average release depths ranged between 100 and $200 \mathrm{~m}$, whereas average depths on the pop-up date ranged from 300 to $350 \mathrm{~m}$. Shallowest, daily, time-weighted mean depths varied among individuals, ranging from $\sim 5$ to $125 \mathrm{~m}$, and deepest, daily, time-weighted mean depths ranged from $\sim 175$ to $515 \mathrm{~m}$ (Fig. 2). Near the end of the tagging period, 8 halibut demonstrated a descent into deep water $(>200 \mathrm{~m})$, occupying their deepest timeweighted mean depth during either December or January. Neither S-133 nor S-139 demonstrated prolonged residence below $200 \mathrm{~m}$ during their time at liberty, and they occupied their deepest time-weighted mean depths in September and July, respectively.

For the halibut that descended to deep water in early winter, the timing of descent varied considerably, whereby descent was defined as persistent residence at daily time-weighted mean depths $>200 \mathrm{~m}$ (i.e. slope waters). For eastern GOA fish, arrival on the slope occurred in fall. All eastern halibut spent the majority 


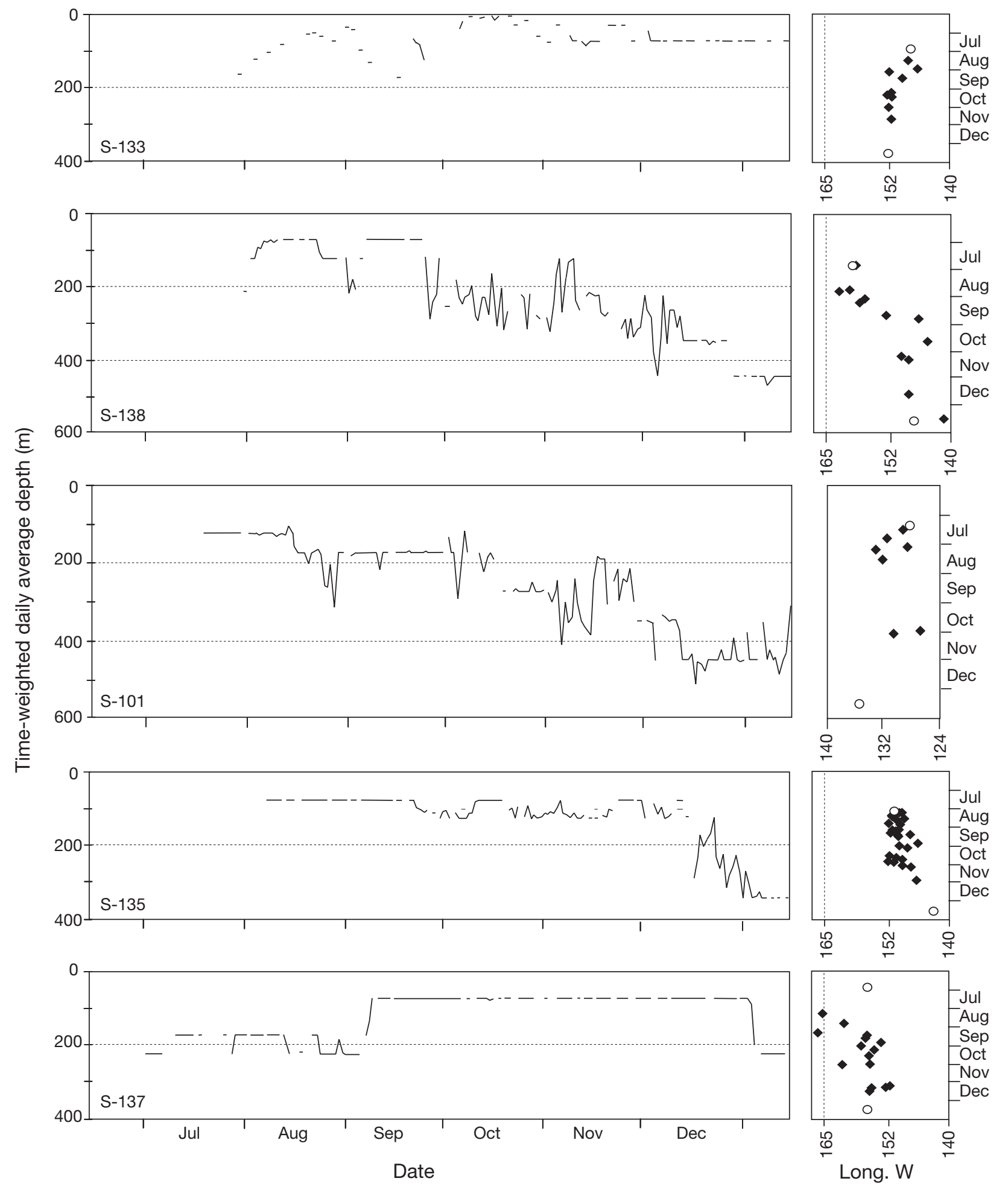

Fig. 2. Hippoglossus stenolepis. Tagged halibut selected as representative of range of behaviors observed from summer 2002 to mid-January 2003: remaining in shallow waters (S-133), slope migration in late summer (S-138), early fall migration (S-101), and winter migration (S-135). Left-hand graphs: time-weighted, daily mean depths experienced. Right-hand graphs: (O) in early summer and mid-January represents tagging and pop-up location, respectively; $(\diamond)$ represent at-liberty longitude estimates determined from daily light data. Note that $124^{\circ} \mathrm{W}$ is the equivalent of the Oregon coast; Yakutat Bay is located at $\sim 140^{\circ} \mathrm{W}$, and Unimak Pass at $\sim 165^{\circ} \mathrm{W}$. S-137 was the only fish to produce longitude estimates suggesting it may have entered the Bering Sea. Note that rapid eastward migration of S-138 in late September suggested by light-based longitude estimates corresponds temporally to its initial movement to slope waters (>200 m) 

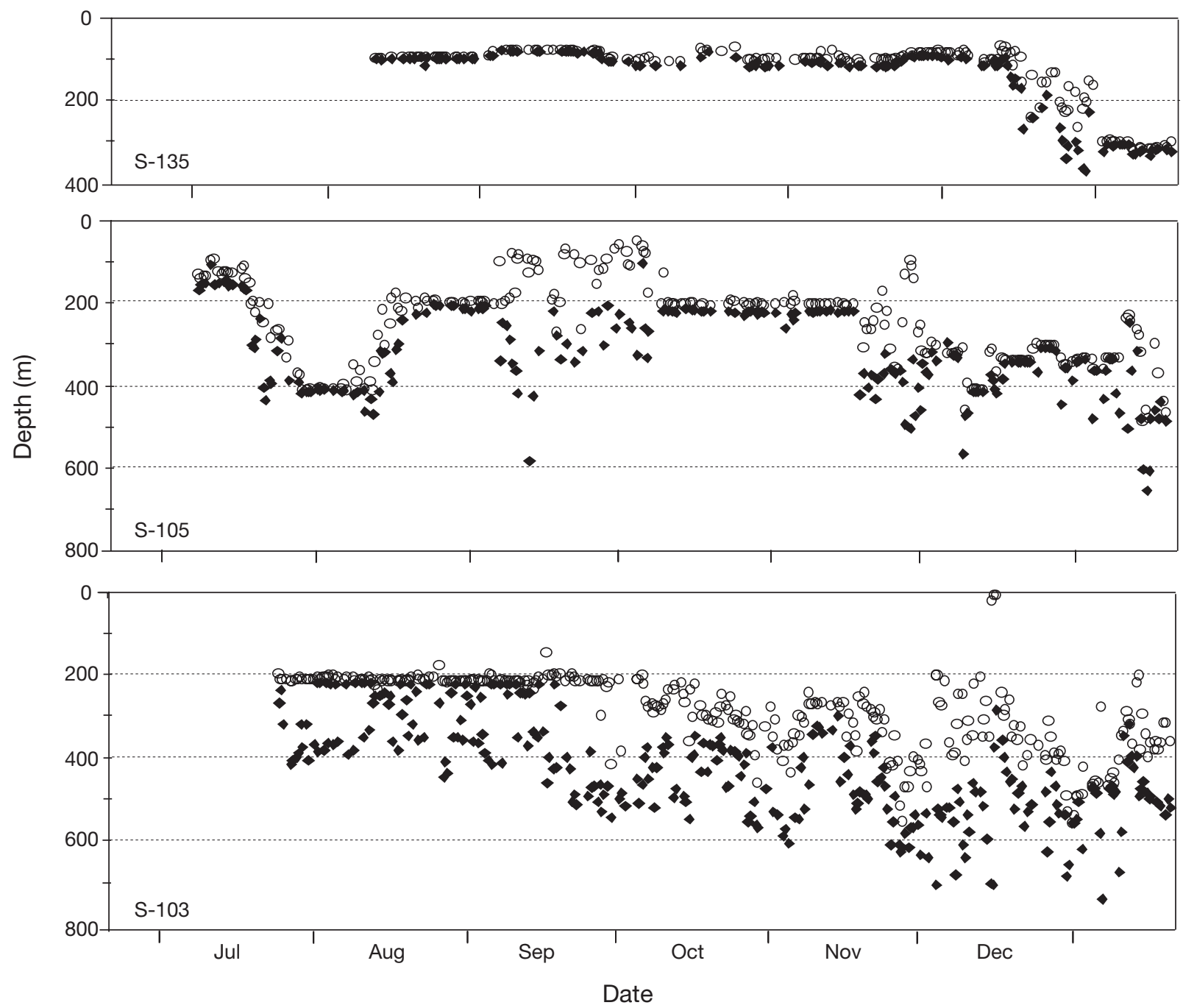

Fig. 3. Hippoglossus stenolepis. Maximum ( $\bullet$ and minimum (O) depths experienced by tagged halibut during $12 \mathrm{~h}$ periods from summer 2002 to mid-January 2003; 3 fish demonstrate the range of common, short-period, vertical behaviors observed: little short-period movement (S-135), periods of activity interspersed with relative 'vertical quiescence' (S-105), and considerable vertical activity through time at liberty (S-103)

of their time at $>200 \mathrm{~m}$ throughout December and January, arriving on the slope some time between September and November (e.g. S-101, Fig. 2; S-105, Fig. 3). Similar to the eastern fish, S-138 first arrived on the slope in early October and remaining persistently below 200 m from early November onward (Fig. 2). In contrast, S-135 (Figs. 2 \& 3) and S-136 remained in shallow water throughout much of fall and early winter, not descending below $200 \mathrm{~m}$ until mid-December and early January, respectively.

Of the 10 halibut, 2 failed to demonstrate directed late-season movement to the continental slope: S-133 and S-139. S-139 spent the summer at depths typical for other halibut (100 to $200 \mathrm{~m}$ ), but did not relocate to deep water by the pop-up date. It regularly displayed daily maximum depths > $200 \mathrm{~m}$ throughout the tagging period, but its daily time-weighted mean depth was $>200$ m on only 1 day. S-133 was even more anomalous (Fig. 2). It moved into mean depths $<25 \mathrm{~m}$ in October, remained relatively shallow throughout the remainder of the tagging period, and was located inside Cook Inlet in mid-January.

Over the shortest time scale available for analysis (depth maxima and minima recorded during $12 \mathrm{~h}$ summary periods), some fish engaged in considerable vertical movement whereas others tended to remain at relatively constant depth. S-102 and S-103 commonly engaged in short-period depth changes of 100 to $300 \mathrm{~m}$ or more, and in the case of S-103 as much as $680 \mathrm{~m}$ (Fig. 3). In contrast, short-period depth variation dis- 

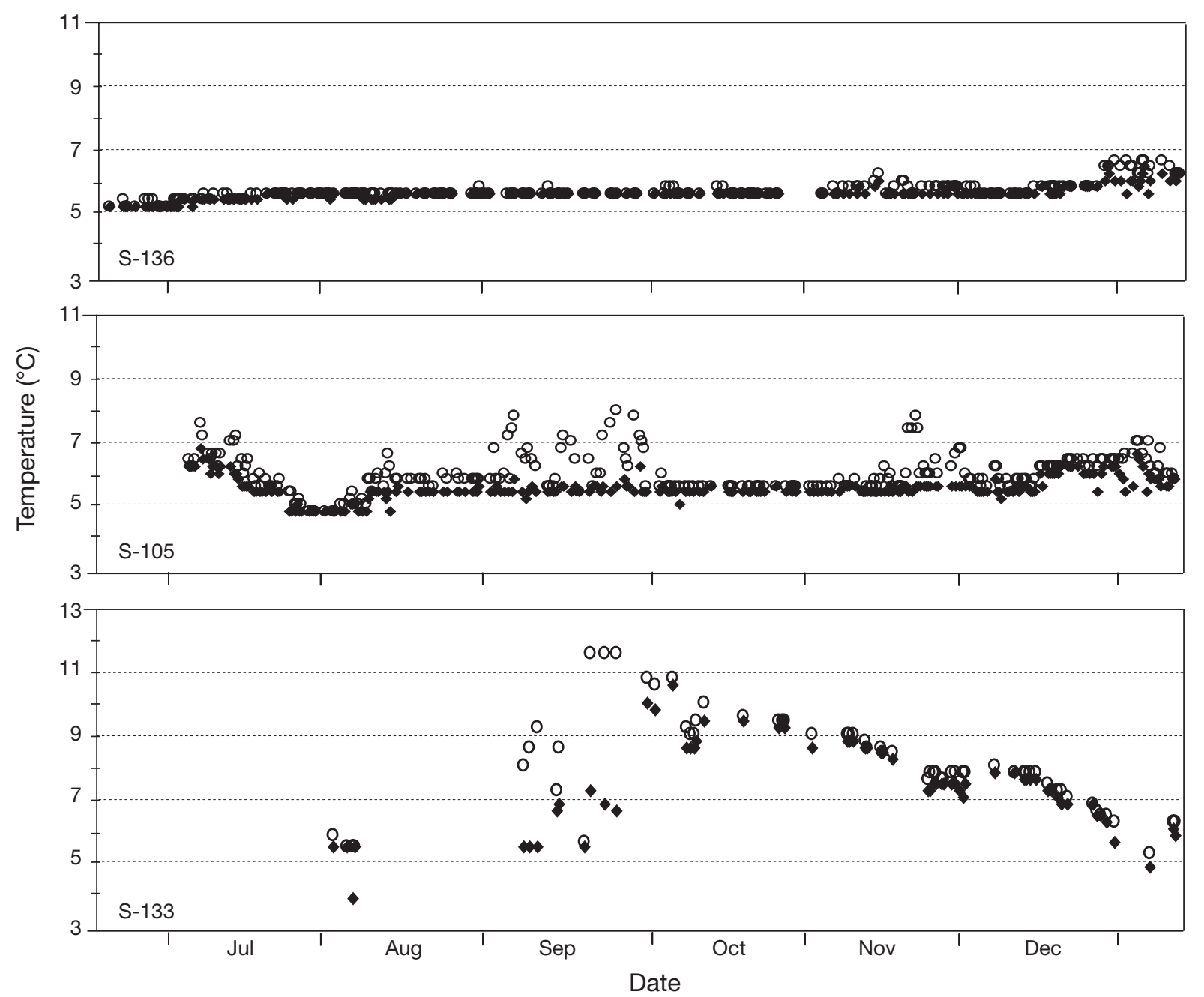

Fig. 4. Hippoglossus stenolepis. Maximum ( $)$ and minimum (O) temperatures experienced by halibut during $12 \mathrm{~h}$ periods from summer 2002 to mid-January 2003; 3 fish demonstrate the range of common temperature profiles observed: little variability while remaining at 3 to $5^{\circ} \mathrm{C}(\mathrm{S}-136)$, somewhat variable temperature with readings occasionally above $7^{\circ} \mathrm{C}(\mathrm{S}-105)$, and considerable thermal variability throughout time at liberty (S-133)

played by S-135, S-136, and S-137 was typically about 1 order of magnitude lower, being rarely more than 20 to $30 \mathrm{~m}$ throughout the summer and fall (e.g. S-135, Fig. 3). Other fish exhibited a combination of behaviors, with periods of vertical quiescence interspersed with periods of considerable activity. For example, S-105 (Fig. 3) generally confined its shortperiod vertical movements to about $50 \mathrm{~m}$ throughout July and August, but became vertically quite active in September, experiencing variations of 100 to $300 \mathrm{~m}$. It then returned to a pattern of restricted vertical movement from early October through mid-November, and reverted to considerable depth variability through early winter. Although somewhat less pronounced, similar shifts in behavior were observed for S-101, S-138 and, late in their tagging periods, for S-135 and S-136.

\section{Temperature}

Tagged halibut experienced temperatures (Figs. 4 \& 5) ranging from $2.6^{\circ} \mathrm{C}(\mathrm{S}-103$, November 12$)$ to $11.6^{\circ} \mathrm{C}$ (S-133, September 20). However, the typical range was narrower, with most fish spending the majority of time at 5 to $9^{\circ} \mathrm{C}$ (Fig. 5). All halibut tagged in the eastern GOA spent the majority of their time at 5 to $7^{\circ} \mathrm{C}$ during all seasons. Western GOA halibut tended to experience more variable conditions, encountering somewhat warmer temperatures. S-133 encountered both the broadest temperature range and the overall warmest conditions, spending considerable time in waters of 7 to $11^{\circ} \mathrm{C}$ throughout the year. Note that this fish was located in Cook Inlet in mid-January and exhibited the shallowest overall depth profile. Only S-105 and S-137 experienced temperatures $<5^{\circ} \mathrm{C}$ for extended periods - dur- 
ing July and August for both fish. However, these cool temperatures were only slightly below $5^{\circ} \mathrm{C}$ : in the case of S-105, the minimum temperature experienced was $4.8^{\circ} \mathrm{C}$ (Fig. 4), and for S-137 was $4.6^{\circ} \mathrm{C}$.

Short-period (within $12 \mathrm{~h}$ summary periods) temperature variability differed among individuals and over time. Some fish were subjected to only very limited changes in temperature (e.g. S-136, Fig. 4), while others experienced considerable short-period fluctuations, the greatest of which approached $5^{\circ} \mathrm{C}$ (S-133, Fig. 4). Shortperiod temperature variability encountered by individual fish was not necessarily consistent throughout time at liberty. In many cases, it was characterized by intervals during which considerable variability was apparent, interspersed with weeks characterized by relative stability (e.g. S-105, September versus October, Fig. 4).

\section{DISCUSSION}

\section{Sex bias}

It should be borne in mind that because of the size of the fish observed, the results presented here may rep-

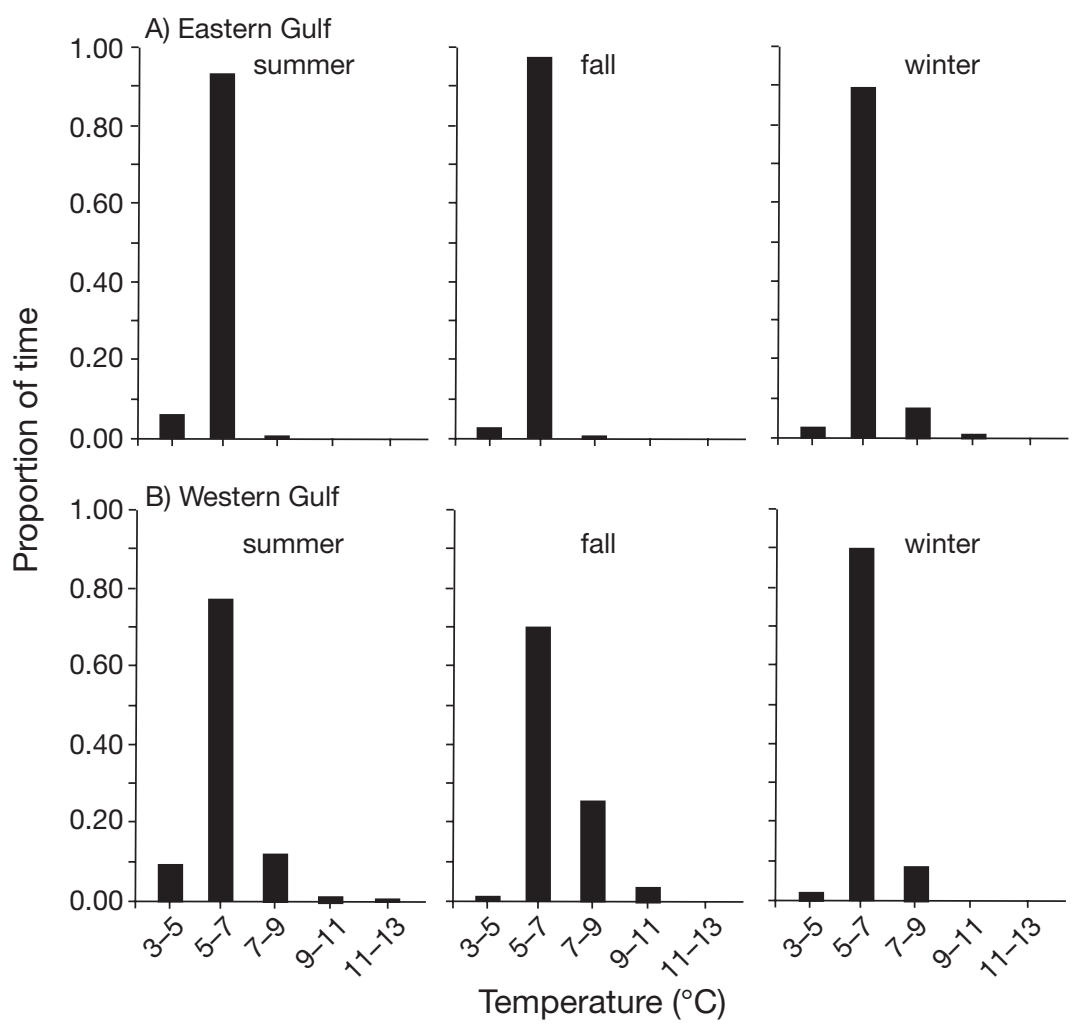

Fig. 5. Hippoglossus stenolepis. Percentage of time spent in each $2^{\circ} \mathrm{C}$ temperature bin during summer (defined as June 1 to September 15), fall (September 16 to October 31), and winter (December 1 to January 15) 2002. Data for halibut have been pooled. Top graphs: halibut tagged in the (A) eastern Gulf of Alaska and (B) western Gulf resent only a specific segment of the halibut population. Preliminary observations (A. Seitz unpubl.) had suggested that swimming behavior can be altered if the tag's antenna comes into contact with the halibut's tail, and so only fish $>100 \mathrm{~cm}$ were tagged. These were most probably reproductive females, and these individuals may have unique energetic needs and employ specific life-history strategies to optimize egg production. Sex-specific variability in seasonal distribution and migration strategies has been demonstrated in other flatfishes (Arnold \& Metcalfe 1995, Sabrowski \& Bucholz 1997), as have temperature-specific differences in habitat choice (Swain 1997). We caution that these results not be extended beyond the adult female component of the population until further research is conducted to determine whether males and pre-reproductive individuals behave similarly.

Identifying proportions of a population that display long-distance migrations versus year-round local residency is central to the study of spatial population structure in mobile species, and a core element to ensuring that stock definitions reflect biology. Movement patterns, extent of overlap between population components, and fidelity to seasonal grounds define the nature of interdependence among groups throughout a species' geographic range. Flatfish species representative of various degrees of segregation can be found in the scientific literature. For example, western Atlantic winter flounder Pseudopleuronectes americanus spawn demersal eggs in estuaries favoring larval retention (Manderson et al. 2003), generating local population structure (Sogard et al. 2001). NE Atlantic Dover sole Solea solea display modest seasonal dispersion, with overlap on spawning grounds (Horwood 1993, Koutsikopoulos et al. 1995), thus largely conforming to a model of separation-by-distance (Exadactylos et al. 2003). Western Atlantic summer flounder Paralichthys dentatus are offshore-spawners (Able et al. 1990) that appear to be reasonably homogeneous with respect to subpopulations north versus south of Cape Hatteras, North Carolina (Jones \& Quattro 1999, Burke et al. 2000). In the present study of eastern Pacific halibut, 
5 general seasonal migration behaviors were apparent from 10 tag returns: (1) northward displacement coupled with movement to deep water along the shelf edge (Fish S-101, S-103, S-135, S-136, and S-138); (2) relatively little displacement, coupled with movement to deep water along the shelf edge (S-102, S-137); (3) little displacement, remaining in relatively shallow shelf-waters (S-139); (4) movement to deep inshore waters (S-105); (5) movement to shallow inshore waters (S-133).

The first 2 behaviors (1 and 2) are consistent with the paradigm of an fall spawning migration to the slope (St. Pierre 1984), and a tendency for halibut to congregate to some extent in the northern GOA in winter (Leaman et al. 2002). Conventional tagging by Thompson \& Herrington (1930), although not designed to examine seasonal movement, provided the first evidence of spawning migrations. Over the course of $3 \mathrm{yr}$, Area 2 fish were tagged during summer and northern GOA fish tagged during winter. Summer returns showed dispersal of northern GOA halibut, but not of those tagged in Canada. The authors attributed the different dispersal patterns to Area 2 fish being less migratory by nature. However, later work demonstrated that Thompson \& Herrington's (1930) results most probably reflected seasonal movement: the dispersion of the northern GOA tag recoveries incorporated the fall migration from spawning grounds back to summer feeding areas, whereas lack of dispersion of summer-tagged southern fish reflected summer-tosummer site fidelity. This was demonstrated by Skud (1977), whose analysis of later tag programs revealed that average distance between tag release and summertime recovery is lower for summer-tagged fish than for winter-tagged fish. Specifically, fish tagged in winter on the Yakutat spawning ground were recovered as far away as western Kodiak and the Shumagin Islands during summer. In the present study, Fish S-136 and S138 followed this pattern, migrating to the Yakutat spawning grounds from release sites west of Kodiak. In Canadian waters, Skud (1977) found that only 1\% of summer-tagged fish were recaptured outside Canada during summer, whereas $52 \%$ of winter-tagged fish were later recaptured in the US. In our study, the data on S-101 and S-103 confirm a long-distance fall migration from Canada to SE Alaska.

From an ecological perspective, the observed longdistance migrations to offshore, putative spawning grounds, coupled with potentially large larval-advection distances (St. Pierre 1989, Bailey \& Picquelle 2002), suggest the potential for considerable mixing. However, local spawners (here, Fish S-102 and S-137) could complicate that conclusion if they exhibit long-term sitefidelity. Mixing could occur in the north-central GOA where halibut congregate to spawn, while local sub- populations are maintained at the range edges. Multiple life-history strategies add complexity, because local feeding grounds might therefore be stock complexes with respect to spawning strategy, and maintenance of all components can be important to preserve within-species biodiversity, adaptive potential, and the stock's compensatory characteristics under exploitation (Frank \& Brickman 2000).

In addition to shelf-edge migrations, 3 fish displayed unexpected behaviors (Behaviors 3 to 5 above; Fish S-105, S-133, S-139) that have not been reported in conventional tagging studies. The observation that S-133 and S-139 did not move to deep water may simply indicate that their offshore migration did not coincide with the programed pop-up date. Spawning is expected to occur until at least March in the Gulf of Alaska (St. Pierre 1984), and a mid-January pop-up may be too early to capture seasonal migration of late spawners. Alternatively, some spawning may occur in shallow shelf-waters or a proportion of the mature population may forego spawning each year. Novikov (1968) reported capture of a substantial proportion of non-spawned mature individuals in the Bering Sea during late-winter surveys and foregone spawning and/or pre-spawn mass atresia have been documented in wild populations of the Greenland halibut Reinhardtius hippoglossoides (Fedorov 1971) and the winter flounder Pseudopleuronectes americanus (Burton \& Idler 1987), and has been experimentally demonstrated in captive North Sea plaice Pleuronectes platessa (Rijnsdorp 1990). Investigation of year-round depth profiles will be required to determine whether mid-January is too early to record the offshore migration of all halibut, or whether some individuals remain at shallow depths throughout the winter. In the case of Fish S-105, movement to the deep inshore waters of SE Alaska may well have represented its spawning migration. Inside waters have not been sampled to determine if they contain important spawning grounds, but large adult halibut commonly occur as bycatch during the winter longline-fishery for demersal shelf rockfish Sebastes spp. as well as in February sablefish assessment charters in Chatham Strait (V. O'Connell, Alaska Department of Fish and Game, Sitka, unpubl. data).

\section{Environmental data}

Although primarily observational, PAT tag data provide insight into halibut behavior and the environmental conditions to which they are subjected in ways not previously possible. The present data demonstrate that summertime activity was concentrated from 0 to $400 \mathrm{~m}$. Halibut that exhibited a late-season movement to deep water were typically observed at depths of 300 to 
$700 \mathrm{~m}$ by mid-January. This is in general agreement with observations by Seitz et al. (2003) for similar-sized halibut tagged in the northern GOA. In that study, summertime activity was concentrated at 50 to $350 \mathrm{~m}$; 2 fish were observed throughout the winter, and the deepest portion of their depth profiles indicated residence at 300 to $500 \mathrm{~m}$ from December through early February. Halibut tagged in the SE Bering Sea undertook similar movements (Seitz et al. in press b), but with somewhat shallower summertime distributions (primarily <200 m) and slightly deeper winter depths (400 to $800 \mathrm{~m}$ ).

Eventual descent to the slope was observed in most individuals in the present study, but timing and rapidity of movement was not consistent. Some fish moved quickly from their summer depth range, whereas others exhibited protracted periods of descent. Interestingly, for western GOA halibut, those tagged near Kodiak Island (S-135 and S-136) and the fish that displayed the least displacement (S-137) did not descend to the slope until December or January. In contrast, the halibut that undertook the most extensive migration (S-138) displayed a more protracted descent, moving below $200 \mathrm{~m}$ in early fall and descending gradually deeper until January. Halibut migrating long distances may leave the shelf earlier than those that spawn locally. In the case of S-138, light-based longitude estimates support the hypothesis that its protracted descent was related to its eastward migration. One must keep in mind that individual estimates can contain errors, but the estimates for S-138 (Fig. 2) followed a consistent west-to-east trend, beginning in August with westerly coordinates near the tagging location and eventually approximating the pop-up longitude by October. This period of eastward travel corresponded to movement from a relatively constant average depth of $75 \mathrm{~m}$ in mid-September to over $300 \mathrm{~m}$ by midOctober (Fig. 2). This is a single observation and more data will be required to quantitatively investigate possible relationships between depth profiles and longshore migration.

On shorter time scales (days to weeks), vertical migratory behavior was quite variable: vertical movement as great as $450 \mathrm{~m}$ within $12 \mathrm{~h}$ was observed during summer and $680 \mathrm{~m}$ in winter. Unfortunately, it is nearly impossible to determine from binned data whether short-period depth changes represented movement into the water column or benthic travel along sloping bathymetry. If the tags are physically recovered and the detailed data accessed, it may be possible to infer movement into the water column based on rate of change in depth. Seitz et al. (2005) observed depth changes as great as $168 \mathrm{~m}$ in $4 \mathrm{~min}$ for adult halibut during winter months, vertical movement of a magnitude difficult to explain as benthic travel. Although submarine canyons are common in some habitats, their observations seemed more consistent with movement into the water column. Halibut are known to forage in the water column, as evidenced by pelagic prey in their diet (Best \& St. Pierre 1986, Orlov 1997) and incidental capture of halibut in the salmon troll-fishery (Gilroy et al. 2004). Movement into the water column during spawning has been observed in numerous flatfishes (Konstantinou \& Shen 1995, Manabe et al. 2000, Manabe \& Shinomiya 2001, Carvalho et al. 2003), and may be exhibited in halibut.

Temperature data demonstrated a tendency for halibut to occupy waters within a range of 5 to $7^{\circ} \mathrm{C}$, with the exception of a few individuals that encountered warmer temperatures for considerable periods. This is similar to results reported by Seitz et al. (2003) for 8 halibut tagged in the NW GOA in 2000 and 2001: fish primarily experienced $6^{\circ} \mathrm{C}$ temperatures during summer and 4 to $8^{\circ} \mathrm{C}$ in winter. Whether this represents active preference or simply reflects ambient temperatures encountered throughout their preferred habitat cannot be determined from the data. However, we hypothesize that the current results are more likely to reflect local conditions than active preference, because the GOA observations depart from data from the SE Bering Sea (SEBS). Halibut in the SEBS have been shown to experience winter temperatures persistently as low as 2 to $3^{\circ} \mathrm{C}$ (Seitz et al. in press b). In addition, the present data demonstrate that halibut can withstand considerable short-period variability of at least $4^{\circ} \mathrm{C}$ within $12 \mathrm{~h}$. Such changes could be caused by the passage of tidally-generated internal waves over relatively stationary fish (sensu Witman et al. 1993) or involve active movement of fish among water masses. Temperature and depth data from archival tags have been used to track the movement of pelagic fish relative to thermoclines (sensu Brill et al. 1999), and the PDT data provided by PAT tags (see 'Materials and methods') may be suitable for identifying depthspecific changes in ambient temperature. Seitz et al. (2003) demonstrated this method for halibut, but we were reluctant to conduct such analyses due to the coarseness of the data and the ambiguities of interpreting short-period depth changes from binned data.

\section{CONCLUSIONS}

Our observations corroborate conventional tagging data, indicating northward movement halibut toward spawning grounds in the north-central GOA, and movement of fish to deep water in fall and early winter. However, no single stereotypic behavior was observed, whether considering seasonal migration, verti- 
cal movement, or temperatures encountered. A number of behavioral patterns were apparent, even with the relatively small number of fish observed: longdistance migration versus remaining in local waters; migration to deep shelf-edge waters versus potential, shallow, winter residence; considerable versus relatively little vertical activity; subjection to eurythermal versus isothermal conditions. Because of the low sample size, this study only provides a glimpse into in situ behavior, but the continued use of archival tags offers the possibility of filling in life-history information gaps not easily elucidated by any other technique.

Acknowledgements. The authors thank those who actively tagged halibut during this study: K. Attridge, B. Biffard, H. Emberton, A. Knott, E. Lardizabal, D. Rafla, J. Spencer and A. Vatter, as well as the captains and crews of the fishing vessels 'Angela Lynn', 'Bold Pursuit', 'Free to Wander', 'Norska', 'Pender Isle', 'Star Wars', and 'Waterfall'. C. Dykstra and K. Ames provided valuable logistical assistance through the IPHC setline survey program. The quality of the manuscript was improved by thoughtful review from B. Leaman, S. Genovese, and our anonymous reviewers.

\section{LITERATURE CITED}

Able KW, Matheson RE, Morse WW, Fahay MP, Sheperd G (1990) Patterns of summer flounder Paralichthys dentatus early life history in mid-Atlantic Bight and New Jersey estuaries. Fish Bull (Wash DC) 88:1-12

Arnold GP, Metcalfe JD (1995) Seasonal migrations of plaice (Pleuronectes americanus) through the Dover Strait. Mar Biol 127:151-160

Bailey KM, Picquelle S J (2002) Larval distribution of offshore spawning flatfish in the Gulf of Alaska: potential transport pathways and enhanced onshore transport during ENSO events. Mar Ecol Prog Ser 236:205-217

Best EA (1977) Distribution and abundance of juvenile halibut in the southeastern Bering Sea. Int Pac Halibut Comm Sci Rep 62:1-23

Best EA, St. Pierre G. (1986) Pacific halibut as predator and prey. Rep Int Pac Halibut Comm 21:1-27

Brill RW, Block BA, Boggs CH, Bigelow KA, Freund, EV, Marcinek DJ (1999) Horizontal movements and dept distribution of large adult yellowfin tuna (Thunnus albacares) near the Hawaiian Islands, recorded using ultrasonic telemetry: implications for the physiological ecology of pelagic fishes. Mar Biol 133:395-408

Burke JS, Monaghan JP, Yokoyama S (2000) Efforts to understand stock structure of summer flounder (Paralichthys dentatus) in North Carolina, USA. J Sea Res 44:111-112

Burton MP, Idler DR (1987) An experimental investigation of the non-reproductive, post-mature state in winter flounder. J Fish Biol 30:643-650

Carvalho GR, Afonso P, Santos RS (2003) The haremic mating system and mate choice in the wide-eyed flounder, Bothus podus. Environ Biol Fish 66:249-258

Clark WG, Hare SR (2002) Density of legal-sized halibut in the eastern Bering Sea and coastwide distribution of exploitable biomass. In: Report of assessment and research activities, 2001. International Pacific Halibut Commission, Seattle, p 407-417
Exadactylos A, Geffen A, Panagiotaki P, Thorpe JP (2003) Population structure of Dover sole Solea solea: RADP and allozyme data indicate divergence in European stocks. Mar Ecol Prog Ser 246:253-264

Fedorov KY (1971) The state of gonads of the Barents Sea Greenland halibut (Reinhardtius hippoglossoides (Walbaum)) in connection with failure to spawn. J Ichthyol 11: 673-682

Frank KT, Brickman D (2000) Allee effects and compensatory population dynamics within a stock complex. Can J Fish Aquat Sci 57:513-517

Gilroy HL, Kong TM, Geernaert TG (2004) 2003 commercial fishery and regulation changes. In: Report of assessment and research activities, 2003. International Pacific Halibut Commission, Seattle, p 33-43

Hays GC, Akesson S, Godley BJ, Luschi P, Santidrian P (2001) The implications of location accuracy for the interpretation of satellite-tracking data. Anim Behav 61:1035-1040

Heifetz J, Maloney NE (2001) Estimation of tag reporting rates for sablefish in the northeastern Pacific Ocean. Alsk Fish Res Bull 8:1-11

Hilborn R, Skalski J, Anganuzzi A, Hoffman A (1995) Movements of juvenile halibut in IPHC regulatory areas 2 and 3. Int Pac Halibut Comm Tech Rep 31:1-44

Horwood J (1993) The Bristol Channel sole (Solea solea (L.)): a fisheries case study. Adv Mar Biol 29:215-367

Jones WJ, Quattro JM (1999) Genetic structure of summer flounder (Paralichthys dentatus) populations north and south of Cape Hatteras. Mar Biol 133:129-135

Konstantinou H, Shen DC (1995) The social and reproductive behavior of the eyed flounder, Bothus ocellatus, with notes on the spawning of Bothus lunatus and Bothus ellipticus. Environ Biol Fish 44:311-324

Koutsikopoulos C, Dorel D, DeSauney Y (1995) Movement of sole (Solea solea) in the Bay of Biscay: coastal environment and spawning migration. J Mar Biol Assoc UK 75:109-126

Leaman BL, Geernaert TO, Loher T, Clark WG (2002) Further examination of biological issues concerning an extended commercial fishing season. In: Report of assessment and research activities, 2001. International Pacific Halibut Commission, Seattle, WA, p 53-74

Loher T, Seitz A (in press) Seasonal migration and environmental conditions experienced by Pacific halibut in the Gulf of Alaska, elucidated from pop-up archival transmitting (PAT) tags. Int Pac Halibut Comm Sci Rep 82

Manabe H, Shinomiya A (2001) Two spawning seasons and mating system of the bastard halibut, Tarhops oligolepis. Ichthyol Res 48:421-424

Manabe H, Miyuki I, Shinomiya A (2000) Mating system of the lefteye flounder, Engyprosopon grandisquama. Ichthyol Res 47:69-74

Manderson JP, Pessutti J, Meise C, Johnson D, Shaheen P (2003) Winter flounder settlement dynamics and the modification of settlement patterns by post-settlement processes in a NW Atlantic estuary. Mar Ecol Prog Ser 253: 253-267

Mecklenburg CW, Mecklenburg TA, Thorsteinson LK (2002) Fishes of Alaska. American Fisheries Society, Bethesda, MD

Novikov NP (1968) Basic elements of the biology of the Pacific halibut (Hippoglossus stenolepis Schmidt) in the Bering Sea. Soviet Fisheries Investigations in the Northeast Pacific, Part 2. (Translated from Russian by the Israel Program for Scientific Translation). US Department of Commerce, Springfield, VA

Orlov AM (1997) Role of fishes in predator diets of the Pacific slope of the northern Kuril Islands and southeastern Kam- 
chatka. In: Forage fishes in marine ecosystems. University of Alaska Sea Grant Rep AK-SG-97-01, Anchorage, AK, p 209-229

Rijnsdorp AD (1990) The mechanism of energy allocation over reproduction and somatic growth in female North Sea plaice, Pleuronectes platessa. Neth J Sea Res 25:279-290

Sabrowski R, Bucholz F (1997) Some observations on the seasonal distribution of dab, Limanda aspera, in the southern North Sea. Helgol Meeresunters 51:41-51

Seitz A, Wilson D, Norcross BL Neilson JD (2003) Pop-up archival transmitting (PAT) tags: a method to investigate the migration and behavior of Pacific halibut Hippoglossus stenolepis in the Gulf of Alaska. Alsk Fish Res Bull 20: 124-136

Seitz A, Norcross BL, Wilson D, Neilson JD (2005) Identifying spawning behavior in Pacific halibut, Hippoglossus stenolepis, using electronic tags. Environ Biol Fish 73: $445-451$

Seitz A, Norcross BL, Wilson D, Neilson JD (in press a) Lightbased geolocation for Pacific halibut (Hippoglossus stenolepis) in the northern Gulf of Alaska: scale and effectiveness. Fish Res

Seitz A, Loher T, Neilson JD (in press b) Seasonal movements and environmental conditions experienced by Pacific halibut in the Bering Sea, examined by pop-up satellite tags. Int Pac Halibut Comm Sci Rep

Editorial responsibility: Kenneth Sherman (Contributing Editor), Narragansett, Rhode Island, USA
Skud BE (1977) Drift, migration, and intermingling of Pacific halibut stocks. Int Pac Halibut Comm Tech Rep 63:1-42

Sogard SM, Able KW, Hagan SM (2001) Long-term assessment of settlement and growth of juvenile winter flounder (Pseudopleuronectes americanus) in New Jersey estuaries. J Sea Res 45:189-204

St. Pierre G (1984) Spawning locations and season for Pacific halibut. Int Pac Halibut Comm Tech Rep 70:1-46

St. Pierre G (1989) Recent studies of Pacific halibut postlarvae in the Gulf of Alaska and eastern Bering Sea. Int Pac Halibut Comm Sci Rep 73:1-31

Swain DP (1997) Sex-specific temperature distribution of American plaice (Hippoglossoides platessoides) and its relation to age and abundance. Can J Fish Aquat Sci 54: $1077-1087$

Thompson WF, Herrington WC (1930) Life history of the Pacific halibut: marking experiments. Rep Int Pac Halibut Comm 1:1-184

Welch DW, Eveson JP (1999) An assessment of light-based geoposition estimates from archival tags. Can J Fish Aquat Sci 57:1317-1327

Witman JD, Leichter JJ, Genovese SJ, Brooks DA (1993) Pulsed phytoplankton supply to the rocky subtidal zone: influence of internal waves. Proc Natl Acad Sci USA 90: 1686-1690

Submitted: June 7, 2005; Accepted: November 15, 2005

Proofs received from author(s): June 16, 2006 